Singing Together Alone: Dynamics Between Individual and Community in Middle Dutch Religious Song Collections

Author(s): Cécile de Morrée

Source: Journal of Medieval Religious Cultures, Vol. 45, No. 2 (2019), pp. 85-112

Published by: Penn State University Press

Stable URL: https://www.jstor.org/stable/10.5325/jmedirelicult.45.2.0085

JSTOR is a not-for-profit service that helps scholars, researchers, and students discover, use, and build upon a wide range of content in a trusted digital archive. We use information technology and tools to increase productivity and facilitate new forms of scholarship. For more information about JSTOR, please contact support@jstor.org.

Your use of the JSTOR archive indicates your acceptance of the Terms \& Conditions of Use, available at https://about.jstor.org/terms 


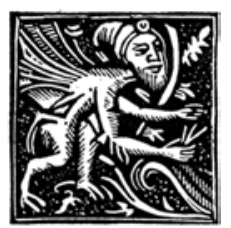

\title{
SINGING TOGETHER ALONE: DYNAMICS BETWEEN INDIVIDUAL AND COMMUNITY IN MIDDLE DUTCH RELIGIOUS SONG COLLECTIONS
}

\author{
Cécile de Morrée \\ Utrecht University
}

ABSTRACT

Scholars of late medieval religious practice have focused on the expression of personal devotion and on the use of individualized devotional texts and books. Particularly manuscript collections of Middle Dutch religious song are thought to have been used in personalized devotional practices of individuals, even though previous research generally did not include codicological analysis. Using both codicological research and textual analysis of twelve Middle Dutch religious song manuscripts and their contents (ca. I470-I550), this article demonstrates that these sources contain indications for both individual use and for use in group activities.

KEYWORDS: devotion, Low Countries, Germany, religious song, Devotio Moderna, individual, community

Over the past decades, scholars have recognized an intensification in the expression of personal piety and in individualized devotional practice in late medieval religious culture. It has been stressed that, in addition to attending communal liturgical celebrations dictated by the church, individual believers had increasing opportunities to develop a personalized devotional practice that matched their individual needs and expressed their emotions. ${ }^{I}$ Manuscripts containing prayers, meditational exercises, and other devotional texts are furthermore often interpreted as individualized products, demonstrating personal preferences and compiled and produced to enhance the inner spiritual development of their intended user. This shift is usually considered to have gone hand in hand with a more general shift of an aural reception toward a visual reading culture. ${ }^{2}$

doi: $10.5325 /$ imedirelicult.45.2.0085

journal of MEDieVAl Religious Cultures, Vol. 45, No. 2, 2019

Copyright (C) 2019 The Pennsylvania State University, University Park, PA 
Personal use or use in individualized devotional practice particularly has been argued for manuscript collections of Middle Dutch religious song. This concerns first and foremost the use of the songs. Based on textual analysis, it has been demonstrated that many songs fit well into a devotional practice that aims for personal spiritual growth and the expression of inner beliefs and that is closely related to practices of meditation and prayer. ${ }^{3}$ In addition to the collections' contents, private names in owners' marks and the apparent uniqueness of these collections have led scholars to conclude that the manuscripts were produced to be used by individuals and compiled to suit the personal preferences of their owners. ${ }^{4}$ This personal or individual use may have been embedded in monastic life as well as elsewhere, but the manuscripts are generally assumed to have been possessed by convents of various religious backgrounds.

However, a close examination of those manuscripts reveals that the matter is more complex than previous research has accounted for. Using both codicological research and textual analysis of twelve Middle Dutch religious song manuscripts and their contents (ca. I470-I550), I will demonstrate that these sources contain indications for both individual use and for use in group activities. Particularly the latter indications are usually overlooked in a present-day debate tending to focus on individualization.

Since the terminology applied here is relatively new to the field of Dutch literary studies, some definitions are useful. Devotion, to start with, can be characterized as the realization of religious beliefs, ideas, and traditions into a certain attitude to life. Devotion, then, consists of two basic elements: on the one hand the theoretical element consisting of, for example, written guidelines or explanatory texts regarding devotional practice, and on the other hand devotional practice itself. This practice, in turn, consists of an inner experience and an outward, perceptible practice. Both the inner experience and the outward practice consist of individual-personal as well as common forms: in any specific example of outward practice, individual and collective acts may be combined. Likewise, any specific inner experience may be influenced by personal-original ideas or emotions as well as by collective mentalities. ${ }^{5}$

This article is concerned with the outward devotional practice. This practice may be closely intertwined with a believer's inner world but it extends outside of the body. In this article, I therefore will use the term individual practice to refer to activities involving one person and I will use the term individual use to indicate that the manuscript, collection, or song was meant 
to be handled or used by one person. I will use the term collective practice to refer to all activities or traditions involving groups of at least two persons, such as the collaboration of scribes or compilers, group singing, or one person listening to someone else singing. Furthermore, the use of specific songs should be distinguished from the use of an entire song collection and from the use of a certain manuscript as physical object. When examined on the material, contextual, and textual levels, Middle Dutch religious song collections point to outward devotional practices that involved individual as well as group activities. ${ }^{6}$

Some pitfalls must be taken into consideration too. As I will demonstrate, in many cases, it is not unequivocally clear whether certain clues should be interpreted as a sign of personal compilation or individual use, or whether they indicate the opposite. Moreover, except for clues regarding their production, the manuscripts offer clues about their intended use only. It remains uncertain whether they were actually used accordingly, since none of them contain notes explaining this. Likewise, owner's marks may reveal that a certain manuscript was - at one moment-in possession of an individual or a collective, but they do not offer conclusive evidence regarding the real use of the book, collection, or songs.

A survey of the scarce information provided by contemporary sources, however, demonstrated that Middle Dutch religious songs were probably used in diverse settings that may have included both individual and group activities. They were sung during liturgical celebrations, during work, for educational purposes, for leisure, and in meditational practices.7 The question of use is further complicated because many instances of use may include situations that serve individual and community at the same time, such as group singing with an inward concentration. Finally, none of the evidence presented here can exclude the possibility that any part of the material investigated has at any moment been used in a different way, as a result of personal preference.

Since most of the manuscripts belonged to convents or are generally assumed by scholars to have originated from convents, in this article I will consider indications of group activities or shared traditions as traces of the communal convent life, even if this assumption is not completely indisputable. ${ }^{8}$ The presence of traces of the communal convent life does not necessarily mean that the manuscripts or their repertoire were used in liturgical celebrations. ${ }^{9}$ As stated earlier, convent life offered more opportunities for collective singing than communal worship and collaborations of scribes or compilers formed part of the collective convent culture as well. It will 
become clear that in this convent culture, individual and community are closely interwoven and that they keep up a constant interplay through vernacular song.

\section{MIDDLE DUTCH RELIGIOUS SONG COLLECTIONS IN MANUSCRIPTS}

From the period ca. I470-I550, twelve manuscript collections of songs in various Middle Dutch dialects have been preserved. ${ }^{\text {Io }}$ The manuscripts vary in size from seventeen to I 86 folia, in octavo. They are made of paper, parchment, or a combination of both materials. In this corpus, I include only manuscripts containing exclusively or almost exclusively songs. In practice, we are looking at collections of seventeen to 235 songs (with most collections containing between fifty and ninety songs), gathered in independent manuscripts. ${ }^{\text {II }}$ Some of these collections contain Latin songs as well as Middle Dutch repertoire. ${ }^{12}$ As one might expect, the great majority of the song texts are about religious themes. ${ }^{\mathrm{I}}{ }^{3}$ In most collections, the melodies are either indicated by a reference to another song on the same tune, or not at all. Only a few manuscripts contain musical scores with written melodies for some of the songs. ${ }^{14}$

In general, scholars agree that these manuscripts were probably produced and used in convents in the Low Countries and in western Germany, particularly the Rhineland, although based on archival sources only four manuscripts can be connected to specific communities. Even though all known possessors are female, we should not yet rule out the possibility that some of the manuscripts were either produced, or at some point owned or used by men.5

Paris, Bibliothèque nationale de France, fonds Néerlandais 39, was in possession of a sister in the convent of Rich Clares in Brussels; Leiden, Universiteitsbibliotheek, BPL I289-II, was at a certain point in the possession of the prioress of the leper house in Heverlee near Leuven; Berlin, Staatsbibliothek zu Berlin-Preußischer Kulturbesitz, manuscripta germanica in octavo I85, was in possession of the St.-Cecilia convent of sisters of the common life in Zwolle, and the Tirs songbook belonged to a sister of the Augustinian convent Niesing in Münster. Of the other manuscripts, no exact place of origin, ownership, or use is known, but a provenance in convents is assumed based on the use of Latin, the Gregorian origins of some of the repertoire, or the skills that were necessary to copy manuscripts with musical notation. 
Although these convents have various monastic backgrounds, it is generally assumed that they did not differ much when it comes to devotional practice, since the spiritual climate in the Low Countries was dominated by the Devotio Moderna. This spiritual reform movement aimed most especially at an improved personal religious growth through the development and transmission of new strategies of immersion in the inner self. During the long fifteenth century (I375-I525), observant movements were arising in convents and communities of various religious orders. Epitomizing this broad tendency, the Devotio Moderna reform movement found resonance in a large part of northwestern Europe. ${ }^{16}$

This cultural background explains why songbooks of Franciscan origin, for instance, demonstrate remarkable similarities in contents to songbooks belonging to Augustinian convents or sisters of the common life. One might even maintain that the collections transmitted in these manuscripts are interconnected in some way, as many of the same songs are to be found in more than one manuscript. This interconnectedness is one of the main reasons to study these collections as a group of sources, beyond the more obvious relatively well-defined time frame in which they were produced. Even so, the use of at least some of the songs was not confined by convent walls. Some individual songs were also transmitted in collections belonging to laypeople and the inhabitants of many late medieval convents maintained an active relation with the urban communities surrounding them. ${ }^{\text {I7 }}$

The interconnectedness of the sources raises the question of the assumed uniqueness of these collections. Although their contents do vary to a large extent, they unmistakably draw on the same repertoire tradition and most collections include the same "religious hit songs" of their time. Also, two examples are known of groups of songs that were transmitted in the same order in several manuscripts, which indicates some common understanding of this repertoire's written transmission. ${ }^{18}$ The actual extent to which song collections varied from another and whether this variation resulted from users' personal preferences thus remains a topic that requires further research.

The song manuscripts offer three types of indications with respect to their use. I will successively discuss the ownership of the manuscripts, their genesis and production, and finally the selection and organization of repertoire, particularly polyphonic songs, Christmas songs, and saints' songs. I will convey the mixed impressions that these collections offer us regarding individual and community and I will discuss some of the problems encountered by current scholarship when trying to determine their 
intended use. By means of a tentative conclusion, I will offer a possible explanation of the dynamics observed between individual and community in Middle Dutch religious song collections.

\section{OWNERSHIP OF THE MANUSCRIPTS}

Five possessors wrote their names in their songbooks around the time the manuscript were produced. All are women: Liisbet Ghoeyvaers, Catharina Tirs, Marigen Remen, Anna van Collen, and Etheken Berntsdachter. Two others, Jenneken Verelst and Johanna Cueliens, wrote down their names a few decades after the manuscripts' production. A few examples of owner's marks:

Dit bock hoert toe Anna van Collen, der et fynt eer et verloeren wort, der sterft ouc wall eer hey kranck wort ${ }^{19}$ [This book belongs to Anna of Cologne, whoever takes it, will die before he grows old]

Catherina Tirs byn ick genanth. Ick stelle alle myne sake in godes hant $^{20}$ [I am called Catherina Tirs. I put my fate in God's hand]

About three of these seven possessors nothing is known, but four of them lived in convents. Liisbet Ghoeyvaers and Johanna Cueliens call themselves “sister." Johanna Cueliens, Catharina Tirs, and Jenneken Verelst can all be linked to sisters in specific convents, based on archival sources. ${ }^{21}$

In many convents - but not all — brothers and sisters took a vow of poverty. In these cases, personal possessions were prohibited or at least discouraged. However, the vast amount of Middle Dutch manuscripts containing private names of brothers and especially of sisters shows that the actual practice was different. In convents of various religious backgrounds, inhabitants could acquire private books in several ways. They could simply copy the books they needed themselves or have them copied for them. They also received books as gifts or legacies from family or friends outside the convent or from fellow inhabitants. Some brothers and sisters were granted a lifelong permission to permanently borrow a book from the communal library for their use only. In short, the private ownership of some of the song manuscripts discussed here is not at all exceptional, although the exact circumstances remain uncertain. ${ }^{22}$

However, personal ownership of a manuscript does not necessarily indicate individual use of that manuscript's contents, nor does it mean that its contents are a personalized compilation, as will be clarified later on in this 
article. We therefore cannot rely on individual owner's marks to investigate a collection's use.

Remarkably, some of these personal marks indicate that actually several users were interested in the manuscripts: some possessors passed on their songbooks to another user. Although not necessarily a source for information about common use, this does indicate a shared interest. Furthermore, in some cases, this interest can be connected with a specific community. Liisbet Ghoeyvaers passed on her book to Johanna Cueliens: "Dit leiisenbuecsken hoert thoe suster Liisbet Ghoeyvaers"23 [This songbook belongs to sister Liisbet Ghoeyvaers]. "Dit boexskens hoort toe suster Johanna Cueliens. Suster Elisabet Ghoeyvaers hevet mij gegeven" ${ }^{24}$ [This book belongs to sister Johanna Cueliens. Sister Elisabeth Ghoeyvaers has given it to me]. Both sisters probably lived in the same convent, which means that the song collection was relevant to several members of this community. 25

Another interesting example is Etheken Berntsdachter, who stated that her songbook should be passed on to the community after her death: "Dit bocsken hoert Etheken Berntsdachter toe ende na mijnre doet so gheve icket int ghemeen" ${ }^{26}$ [This book belongs to Etheken Berntsdachter and after my death I give it to become common property]. Thus, these owners' marks, though containing private names, cannot be interpreted as indications of personalized devotion without further study. Rather than indicating that these collections were personal compilations, they show us that some song collections were important to several persons within a community.

\section{GENESIS AND PRODUCTION OF THE MANUSCRIPTS}

Many song manuscripts have a complex genesis. They usually consist of an initial collection, copied by one scribe, which was extended by other scribes who copied additional stanzas, headings, or songs into blank spaces or inserted additional leaves or quires. ${ }^{27}$ Some of these leaves and quires were inserted specifically for adding new material, while others were most likely sections of other song collections that were thus reused. Some of these later additions are nearly contemporary to the initial collection and at least one collection may have been produced by up to nine different scribes. Furthermore, several songbooks differ from other growing manuscripts because their makers in many ways anticipated and facilitated the growing process. They did so most notably by having the quire structure coincide with the thematic organization of the texts and by providing numerous 
blank pages at the end of each thematic section. ${ }^{28}$ The layered genesis, then, may well be the result of a continuous process of individualizing material, allowing users to adapt the books to their personal preferences. At the same time, however, it demonstrates that several successive scribes or owners were interested in these song collections and indicates a collective interest.

Copied songs were very rarely erased. Instead, several individuals strove to conserve the collection and to contribute to it. In Berlin, SBB-PK, mgo I85, a later scribe added a melody reference to a song written by an earlier scribe. In both Berlin, Staatsbibliothek zu Berlin-Preußischer Kulturbesitz, manuscripta germanica in octavo 280, and Paris, BnF, Néerl. 39, one scribe finished a song text that was started by another. Although in the latter case it remains uncertain whether the ending provided by the later scribe would have matched the ending that the first scribe had in mind, this does seem to be the case for Berlin, SBB-PK, mgo 280. The relevant song in this collection (song no. 76) was also preserved in the Werden songbook (song no. I4), and both versions have the same ending. Also, the melody reference added to Berlin, SBB-PK, mgo I85, indicates that this later scribe knew at least one melody to which the song could be sung. Therefore, she or he must have been familiar with the song. Later scribes were able and motivated to complete unfinished song texts, which demonstrates that to a certain extent a shared knowledge of and interest in this repertoire existed.

At the same time, however, the contributions of later date may well be the result of personal preferences. Particularly the few texts that are written in an unpractised hand, such as the prayer in Paris, BnF, Néerl. 39 (fols. $76^{\text {r- }}$ $\left.{ }^{v}\right)$, may be interpreted as a sign that the manuscript in question was at one point used in a personal devotional practice. Since the manuscripts were at least in some cases passed on from one possessor to another, it is quite plausible that every subsequent owner adapted the collection to her or his individual practice. These later additions could therefore result from efforts to personalize the manuscripts. Yet, the exact motives for the additions are difficult to uncover due to a lack of user's notes.

I will therefore focus on the codicological and palaeographical evidence regarding the manuscripts' production in general. Most importantly, the similarities in layout and rubrication between the different scribes within one codex are remarkable. Also, within the same manuscript the scribes generally structured the songs in the same way. Paris, BnF, Néerl 39, for example, consists of an initial collection of six quires copied by one scribe. A second scribe copied several texts on pages that were left blank by the first scribe and she or he extended the collection by adding four quires. ${ }^{29}$ 
Both scribes worked in a similar manner. They wrote nineteen rules on a page. They marked the beginning of songs with a red initial of two and occasionally three rules high. They separated stanzas with a blank space and marked the beginning of each stanza with a red paragraph sign. Every verse of the song text starts on a new line. The beginning of each rule and verse is marked with a red capital; the end of each rule is marked with a black dot. The scribes also wrote in a similar script (figs. I and 2).

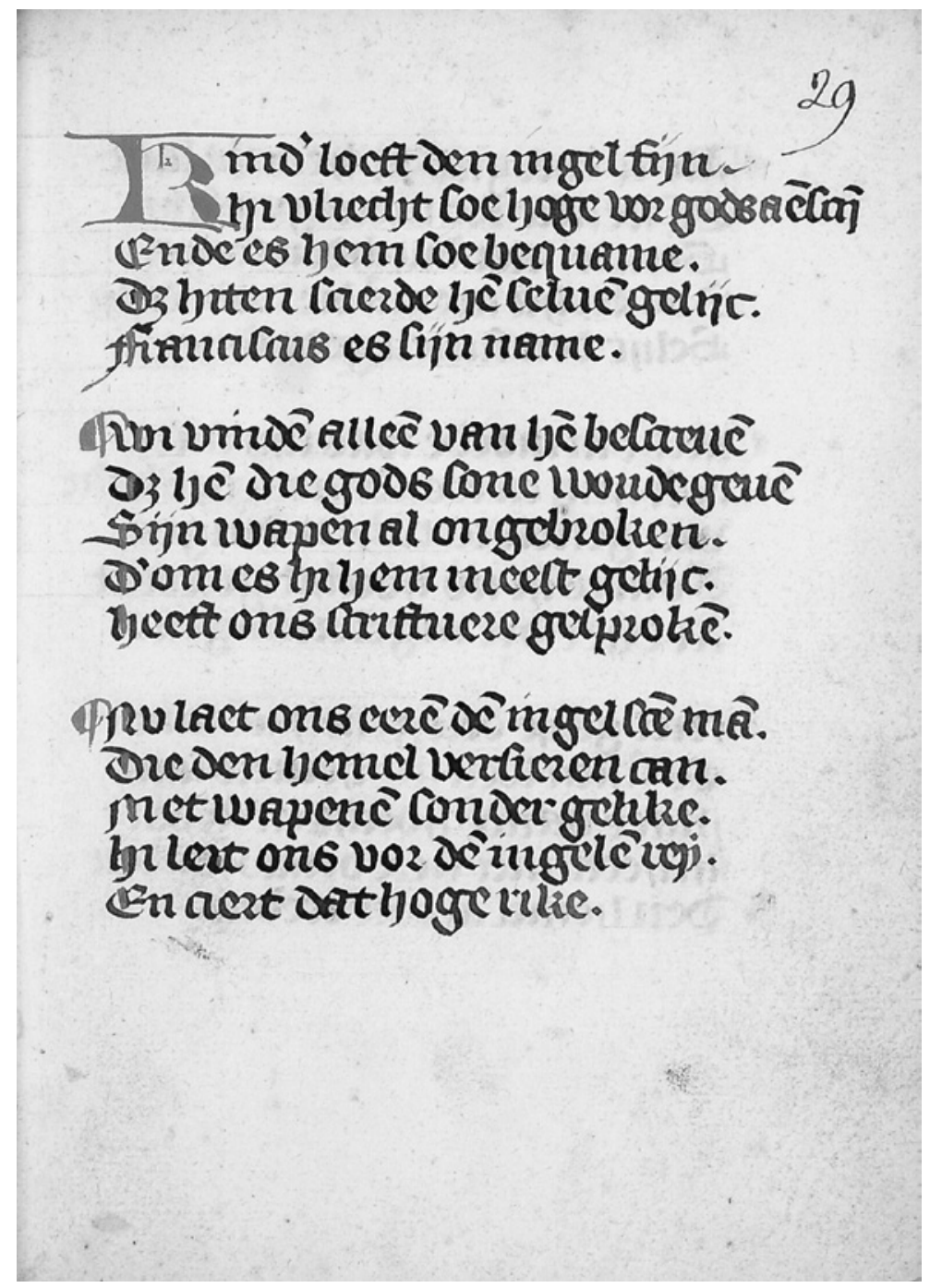

FIG. I “Paris, BnF, Néerl. 39, scribe A," Paris, Bibliothèque Nationale de France, Fonds Néerlandais 39, fol. 29 ${ }^{\mathrm{r}}$, ca. I475-1525, (C) Paris, Bibliothèque Nationale de France. 


\section{$\Leftrightarrow$ es natuex mot b Colless Wúc tiftudi os b teare ill tueb ir b tous norls greotent Cot goo lod ar my ficeten}

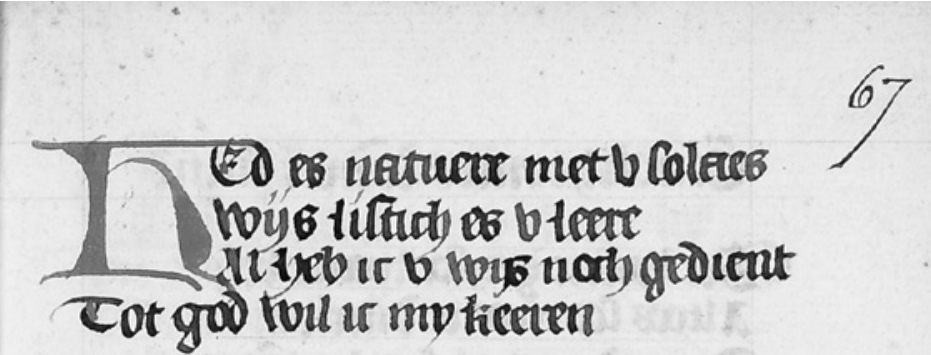

\section{Tar heb gemunt is tuar biblut Dortucire en toones niet later

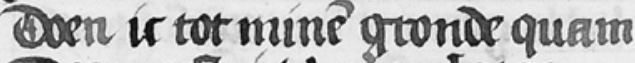 Dor moett it baten Itaten}

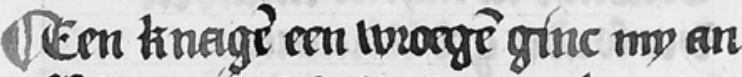 all is mine gronter neme toare Bar is minet het tie lieb gement Dat boll ur laten bautr}

\section{Dorl dat ur ban hem we lat Die mev for leere mince enjeb gedre natucte tract}

FIG. 2 "Paris, BnF, Néerl. 39, scribe B," Paris, Bibliothèque Nationale de France, Fonds Néerlandais 39, fol. $67^{\mathrm{r}}$, ca. $1475-1525$, (C) Paris, Bibliothèque Nationale de France.

Moreover, these scribes probably worked in the same environment. They used the same kind of paper and the same Brabantine dialect. Also, they were interested in the same saints: Francis, Clare, and Barbara. These saints were of great importance to the particular convent of Rich Clares in Brussels, where one of the manuscript's subsequent possessors was prioress in 1580 . At some point, the manuscript was bound together with two printed letters, one explaining how to obtain the papal indulgence in 
the church of St. Gudula in Brussels, and the other by the archbishop of Mechlin, containing additional advice for those who were unable to visit the church, such as monks and nuns. Although these letters date from I603, about a century after the manuscript was produced, it seems likely that the book remained within the same community during that whole period. ${ }^{3 \circ}$

Other examples of similarities between scribal methods within one codex include the resemblance between the two main scribes of Berlin, Staatsbibliothek zu Berlin-Preußischer Kulturbesitz, manuscripta germanica in octavo I90, between the two main scribes of Berlin, SBB-PK, mgo 280, and between most of the scribes of Berlin, SBB-PK, mgo I85.

In spite of internal similarities, layout and rubrication differ from one manuscript to another. In some collections the songs are marked with headings, in some the names of the melodies to which the songs should be sung are included, and in some every song concludes with "amen." Initials differ in color, height, and decoration. In some collections, every song starts at the top of the page and in some every verse starts on a new line. In other collections, the texts are copied continuously, without the beginning of a stanza or a verse being marked. Although all are written in one column and most are paper manuscripts with minimal decoration, both the varieties of layout applied in different manuscripts and the similarities within one manuscript are remarkable.

For some manuscripts, it can be argued that the added texts and quires were produced especially to enlarge a specific collection, and that therefore the later scribe consciously imitated her or his predecessor. This may indeed be the case for Paris, BnF, Néerl. 39, and Berlin, SBB-PK, mgo I9o, but it is not the most plausible explanation for all manuscripts.

The nine scribes who contributed to Berlin, SBB-PK, mgo I85, for instance, demonstrate that later scribes did not imitate their predecessors haphazardly. This codex contains a collection of seventy-eight Middle Dutch songs copied by one scribe, to which eight scribes added a total of fourteen Middle Dutch songs and two short Latin hymns. All additions were copied into blank spaces, no folia were added. Of these eight scribes, six applied the same layout and rubrication as the first scribe, but two other scribes opted for something completely different. ${ }^{3 \mathrm{I}}$ The similarities cannot result from lineation that was previously applied, for there is none.

Manuscript Berlin, SBB-PK, mgo 280, is another telling example. In this codex, two quires were inserted into a manuscript that was initially copied by one scribe. These quires were most likely remains of another manuscript that was produced independently, but in the same environment: the quires were copied by another scribe, who partly used the same kind 
of paper as was used for the manuscript by the first scribe. At least one of the quires is a fragment; the final song ends in mid-sentence and was completed by the first scribe. Even so, the first collection's arrangement shows that it probably already existed when these quires were added..$^{22}$

Both scribes worked, again, very similarly (figs. 3 and 4). They wrote about sixteen rules on a page. Songs do not start at the top of a page, but are

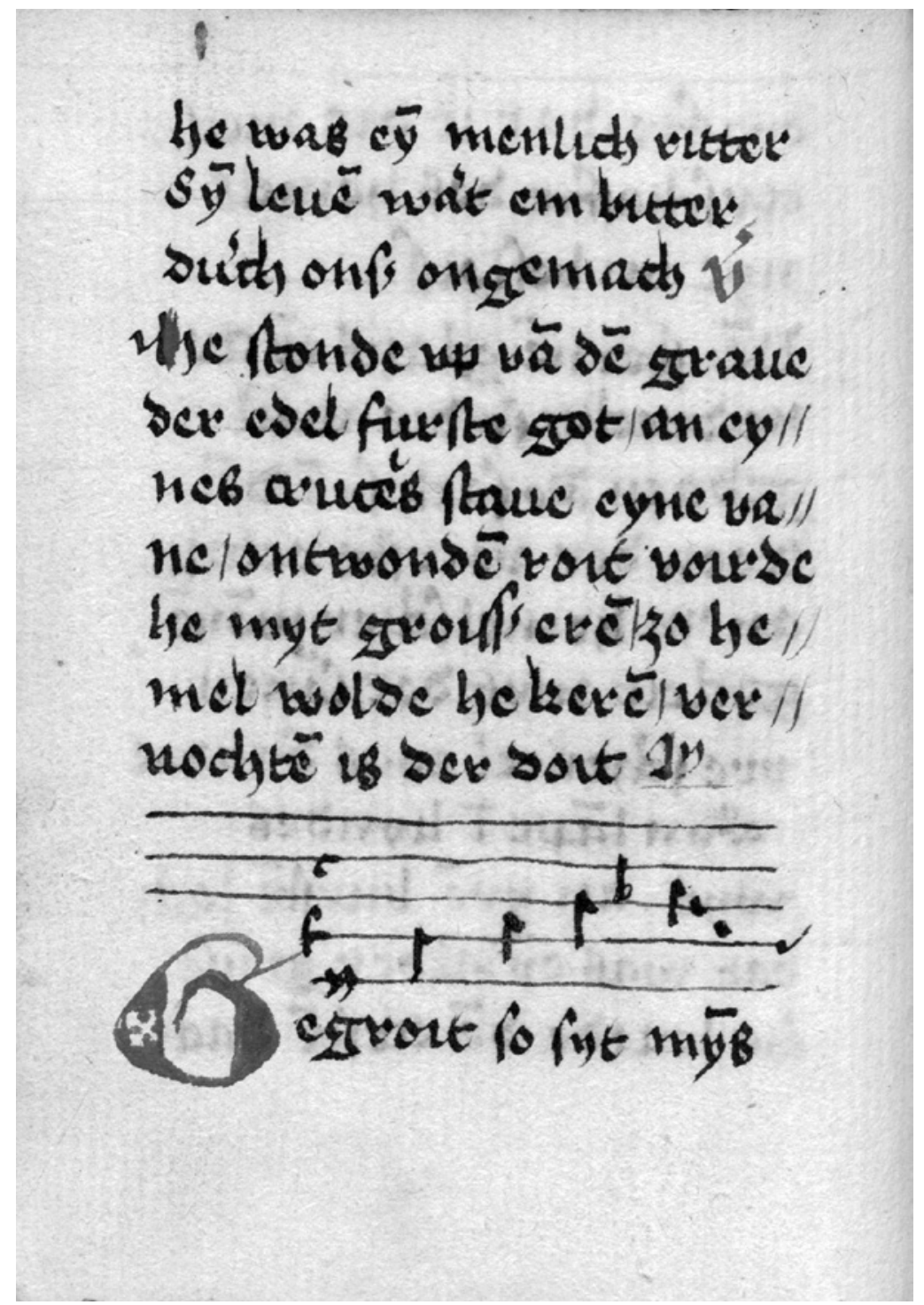

FIG. 3 "Berlin, SBB-PK, mgo 280, scribe A," Berlin, Staatsbibliothek zu Berlin-Preußischer Kulturbesitz, mgo 280, fol. I08", ca. 1525-50,

(C) Staatsbibliothek zu Berlin, reproduced with permission. 


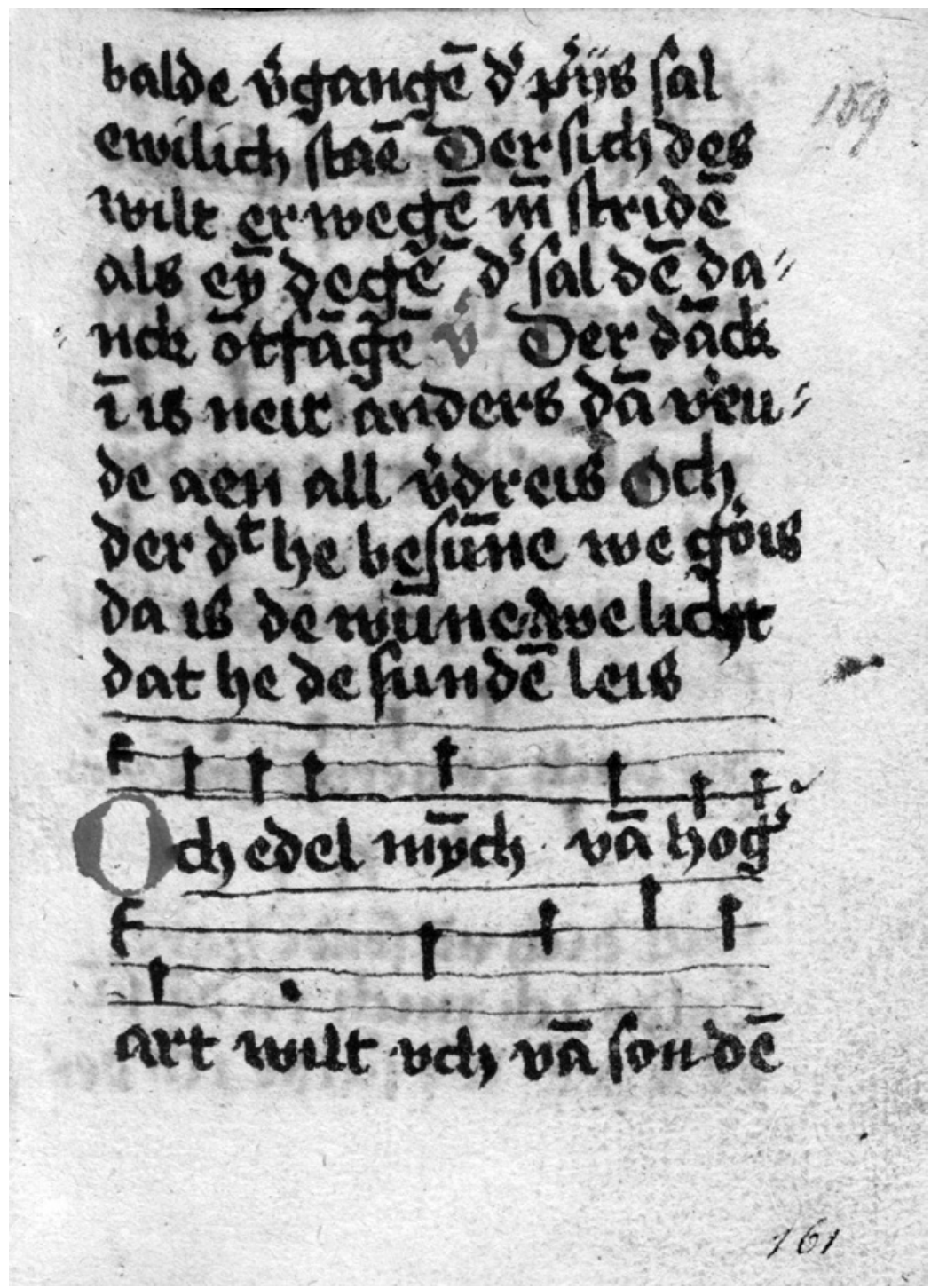

FIG. 4 "Berlin, SBB-PK, mgo 280, scribe C," Berlin, Staatsbibliothek zu Berlin-Preußischer Kulturbesitz, mgo 280, fol. I59 $9^{\mathrm{r}}$, ca. I525-50,

(C) Staatsbibliothek zu Berlin, reproduced with permission.

written one directly after the other. The same holds true for the stanzas and verses: they do not start on new lines but all text is copied in a continuous manner. Songs start with a red initial of two rules high. The stanzas are separated by a red $V$,', which is an abbreviation for the Latin versus. The scribes also wrote in a similar script and used the same type of musical notation (the so-called hufnagel notation). Like the scribes of Paris, BnF, Néerl. 39, 
they used the same kind of paper and they wrote in the same Ripuarian dialect. This example shows that within one environment two independent song manuscripts were used that were produced in a similar way.

There are many different ways to lay out and structure songs (compare figs. 3 and 4 to figs. I and 2, for example). In some cases, scribes who made later contributions to existing song collections and who applied the same layout as previous ones, may have imitated their predecessors. However, I would argue that we should also consider the possibility that scribes worked alike because that was the way they were used to producing songbooks in that particular community, especially in those cases where it seems highly likely that both scribes worked in the same environment, such as is the case for Paris, BnF, Néerl. 39, and Berlin, SBB-PK, mgo 280. The internal similarities within one codex also account for the differences between the various manuscripts: these differences may result from differing local traditions of songbook production. Users had various options to customize their songbooks, such as the later addition of songs or the insertion of severed preexisting quires, but at the same time, the addition of layer after layer made these objects the result of a common effort.

\section{SELECTION AND ORGANIZATION OF REPERTOIRE}

Like the material dimension of the multi-scribe manuscripts, the contents of the collections also show traces of both individual and community. These are particularly visible within three groups of repertoire: polyphonic songs, songs about Christmas, and songs about saints. Because these thematic groups have not been the main focus of previous scholars who demonstrated that many religious songs fit well into an individual devotional practice, it is worthwhile to take a closer look at them.

\section{Polyphonic Songs}

Four manuscripts contain polyphonic songs with musical notation for two voices. These are: Brussels, Koninklijke Bibliotheek, II 270-B; Berlin, SBB-PK, mgo 280; Berlin, SBB-PK, mgo I9o; and Vienna, Österreichische Nationalbibliothek, Codices, Series nova I2875. Only in the first manuscript are the different voices systematically copied parallel to each other: one voice is copied on a verso page, and the other on a recto page. This is customary in choir books and it allows several users to sing polyphonic music from one book. 
In the other three manuscripts, however, the voices are copied one below the other. This indicates that these manuscripts were more likely to be used by one singer. One of these individual singers may have been Anna van Collen, who identified herself as the owner of Berlin, SBB-PK, mgo 280.

However, polyphonic repertoire is an indication of group singing. This means that the-presumably_-personal songbook of Anna van Collen prepared this individual for participation in a group activity and was not intended solely for an individual devotional practice. Although the manuscript as an object was used by an individual, at least part of the song collection was used by the community.

Of Brussels, KB, II 270-B, and Berlin, SBB-PK, mgo I90, as well as one other manuscript, previous scholars have argued that they were used by a convent's choir director. All three collections contain a combination of Latin and vernacular repertoire that might have been used in the preparation or performance of liturgical celebrations. 33 These, again, are examples of an individual use of a manuscript within communal singing activity.

\section{Christmas and Saints' Songs}

Textual analysis has demonstrated that many Middle Dutch religious songs fit in well with individual devotional practices. They bear strong thematic and structural resemblances with prayers and meditation texts. ${ }^{34}$ Also, many songs present a lyrical I persona, which previous research has suggested appeals to the individual. ${ }^{35}$ However, on closer inspection, these observations made by previous scholars relate to only part of the repertoire that is discussed here. Whereas songs about the Passion, the Paschal Triduum, Ascension, heaven and hell, virtue, sin, and repentance generally seem apt vehicles for voicing an inner spiritual experience, songs about Christmas and the veneration of saints generally appeal to a communal context that is represented by a lyrical "we." Thus, when interpreting the texts of single songs in relation to individual and community, an interesting pattern can be recognized that is related to the thematic organization of the collections.

Although Middle Dutch song collections seem to be governed by several organizational principles, most are to some extent arranged according to the annual festive cycle. This arrangement allows the user to find and select songs for specific occasions throughout the day, week, and year, thus commemorating and reliving the main events of the liturgical 
calendar. Still, none of the collections provide an accurate or explicit guide for a liturgical service. Given the themes, it is conceivable that some songs fulfilled some role in ritualized forms of worship, although there is no evidence revealing in a detailed manner what these celebrations really implied. ${ }^{36}$

Christmas, New Year's, and Epiphany songs are usually grouped together in a Christmas season or winter section. Likewise, songs suited for Lent, Passiontide, Easter, and Ascension are gathered in a Lenten and Easter season or spring section, which is often joined together with songs on eschatological themes that fit in with the liturgy of the summer period. Saints' songs are either grouped together or clustered with the season that is nearest in date to the feast day of the saint in question. Some sections have titles that relate them to specific seasons. Generally, each thematic section is copied onto a different quire or set of quires, which confirms that the sections were formed intentionally.37

This division of the collections into seasonal sections coincides with a difference between songs written in the first person singular ("I" songs) and those written in the first person plural ("we" songs) or from a more neutral impersonal narrative perspective. Song texts that repeatedly refer to the individual are grouped mainly in the spring and summer sections. In contrast, songs for Christmas and for saints are mostly written in first person plural. They also sometimes contain incitement to collective action or references to a community. As illustrated by the following quotations, this pattern is best represented by the collections preserved in the manuscripts Berlin, SBB-PK, mgo I85; Berlin, SBB-PK, mgo I90; Berlin, SBB-PK, mgo 280; Paris, BnF, Néerl. 39; and the Tirs songbook, for in these collections the seasonal structure is particularly well articulated..$^{8}$

Examples taken from the spring and summer sections (Lent, Passiontide, Easter, and Ascension songs, songs on eschatological themes, sin, and repentance):

Ich sach her Jhesus van Nazaret op eynen esel ryden 39

[I saw Lord Jesus of Nazareth, riding a donkey]

Hi es neder ghecomen, wair in ic bin verblijt.

Misdaet soud my verdomen;

sijn doot heft my ghequijt ${ }^{\circ}$ 
[He has descended, which rejoiced me.

Sins would damn me;

His death has delivered me]

O Jhesus, alreliefste here, ic byn noch jonc ende teder, ic heb di lief, dat is ommer waer, mer din cruce dat is mi voel te swaer ${ }^{4 \mathrm{I}}$ [Oh Jesus, my dearest lord, I am young and fragile still, I love you, that much is true, But your cross is much too heavy a burden for me]

Ick bidde dy, leve here,

Dorch dyne godlike cracht

Dattu treckest myn herte

$\mathrm{Al}$ an des cruces ast ${ }^{42}$

[I pray you, dear Lord,

That, through your divine power,

You will pull my heart

To the beam of the cross]

Examples taken out of the winter sections (Christmas and Epiphany songs):

Kinder, swijcht, so moecht di horen ( . . . ) hoe heer Jhesus is gheboren ${ }^{43}$

[Children, be silent, then you may hear ( . . . ) how Jesus the Lord was born]

Soe helpten my alle loven ${ }^{44}$

[All (of you), help me praise him]

$\mathrm{Nu}$ moghen wi wel dancken den maghet dien droech 45

[Now we must thank the virgin who carried him]

Gy papen, synget up ju choer,

Gy junckfrouwen, holdet den tenoer 
na mesterliker kunsten,

Ock synget gemeynlike, man und wyff,

Mer vuricklike dan alto styff! ${ }^{4}$

[You priests, sing in your choir,

You maidens, hold the melody

as skillfully as you can,

Man and woman, sing together,

High-spirited and not stiff!]

Examples of saints' songs:

Kinder, nu loeft die maghet Marie ${ }^{47}$

[Children, now, praise the virgin Mary]

Loeft, alle die hier bi my sijn, een ioncfrouwe edel ende fijn! ${ }^{4}$

[All who are present here with me, praise a noble and pure maiden!]

Gruet ons Franciscus onsen vader,

Ons patroens sidi bey gader,

Bevolen blive $\mathrm{u}$ al ons covent! 49

[(St. Clare,) Greet for us our father St. Francis,

Both of you together are our patron saints,

We commend you our entire convent!]

Laet ons aenroepen $\left(.\right.$. ) onse hilige patroensche Cecilia! ${ }^{\circ}$

[Let us invoke ( . . . ) our Holy patroness Cecilia!]

$\mathrm{Nu}$ hoert wat ic u sal verclaren, ( . . ) van eenre joncfrouwen geheten Sante Gheertruyt ${ }^{51}$

[Now, listen to what I shall explain to you ( . . ) about a maiden called Saint Gertrud]

One might wonder whether singular pronouns in the song texts always refer to the individual and whether plural pronouns refer to the community. Helpful here is Zumthor's distinction between a universal, narrative "I" and a personalized "I" who implicitly or explicitly addresses a "you." ${ }^{2}$ The "you" addressed by the lyrical "I" that figures prominently in the spring and summer sections either remains implicit or represents an absent or abstract figure, such as God, Jesus, or a certain 
virtue, which is addressed in the second person singular. This "I" may be filled out by any user of the text according to her or his personal situation and preference. This makes these songs excellent vehicles for personal expressions of piety.

In the winter and saints' sections, however, we find an "I" addressing a plural "you," which refers to those present around the "I." Moreover, these listeners are incited to actively participate in the activities of song and praise initiated by the "I," thus engaging in group activity. This creates a certain sense of community within the song text, which is strengthened by the prominence of a lyrical "we" in these songs. Also, in addition to the optional personalization of the "I" and "we" according to individual preference, it seems the textual sense of community in the winter and saints' songs can in some cases be identified with a real sense of community. This becomes apparent from the collective praising of saints who are addressed as "our patron" or "the patron Saints of our convent."

It is true that a literary analysis of song texts does not permit incontrovertible conclusions about the songs being actually used in either personalized devotion or in group activities. As mentioned in the introduction to this article, information about actual vernacular singing practice in convents in the Low Countries and the German Rhineland is, unfortunately, scarce. ${ }^{53}$ However, the use of plural forms and collective incentives in Christmas and saints' song texts seems to correspond with the scarce and rather general information that is available about the celebrations of these occasions.

The idea of Christmas songs functioning in group activities matches the special status of this feast. Especially in the many Devotio Moderna convents, polyphony was allowed only at Christmas time to highlight the joyous festivity of the occasion. By definition, this particular musical style included at least two participants. Additionally, in some parish churches, vernacular Christmas songs formed an integral part of the Latin liturgical celebrations. Some parish churches were frequented by sisters of the common life, for many communities did not acquire a convent chapel until the very end of the fifteenth century. There are also some indications that these songs were sung not only by the clergy, but by the whole congregation. ${ }^{54}$

The strong connection between Christmas and vernacular singing may also be reflected by the sheer number of Christmas songs that have 
been preserved. Christmas songs are the largest thematic group preserved and almost all Middle Dutch religious song collections contain a group of them. Moreover, these songs are usually featured by a prominent position: most collections start with Christmas songs. 55 In other words, there are several indications that singing was a popular activity at this time of the year, and that singing, on some occasions at least, took place in groups.

In the same way, a communal use of saints' songs is probable because the worship of specific saints was often locally determined. Middle Dutch song collections usually contain only songs about those two or three saints that were of particular local importance. Examples include the manuscript belonging to the Rich Clares (Paris, BnF, Néerl. 39), and the collection in Berlin, SBB-PK, mgo I $85 .{ }^{56}$

No less than three collections consist mainly or almost exclusively in selections of Christmas and saints' songs, thus indirectly facilitating collective singing activities. The first of those is the one transmitted in Paris, BnF, Néerl. 39, which successively belonged to two convent sisters. The two other relevant manuscripts, Vienna, ÖNB, cod. ser. nov. I2875, and Brussels, KB, II 270-B, combine Christmas and saints' songs with polyphonic repertoire and therefore seem particularly intended for use in group singing.

In comparison, the corpus includes only one collection that consists predominantly of songs that appeal to the individual. Manuscript Leiden, Universiteitsbibliotheek, LTK 2058, explicitly presents the possibility of using the songs according to a biweekly meditation scheme. 57 The manuscript was indeed, at some point, in the possession of an individual, Etheken Berntsdachter. In two texts, the plural forms "susters" and "susterkijns" (sisters) are changed into the singular "suster" (sister) by erasing a few letters..$^{8}$ The manuscript is also the only Middle Dutch song manuscript that contains illustrations, thus allowing for a visual- possibly silentreception to inform or dominate an aural one.

Yet, in spite of the exceptional individual character of this collection as a whole, it too must have functioned as a part of communal tradition. Etheken Berntsdachter wished to bequeath the book to the community and it is the only song manuscript that explicitly refers to communal ownership. Furthermore, its contents are partly rooted in written traditions that were known to scribes of three different manuscripts. 59

Finally, it is worth mentioning here a particular song about Mary included in the Werden songbook. This song is introduced by a short exemplum and 
the comment that whoever carries this song with them, reads or sings it, or listens to someone else reading or singing it, will receive an indulgence and will be protected from smallpox. ${ }^{60}$ Although some examples are known of devout sisters carrying with them small pieces of paper containing biblical quotes, I do not know of any other song with a similar talisman function. Also, although examples are known of Latin prayer books being carried around for personal protection, a single comment to one song cannot be extended to an entire song collection. ${ }^{6 \mathrm{I}}$ The comment, however, remains an intriguing one with respect to this article's scope: the protection can be acquired both by individual and collective use of the song.

\section{TOWARD A CONCLUSION}

Middle Dutch religious song collections do not show a clear, coherent kind of devotional use that is either individual or common. Different observations can be made about the use of the physical book, the use of the collection as a whole, and about single songs. The conclusions that can be drawn depend on what exactly it is one studies.

Middle Dutch song collections represent both individual and community, and working with these dynamics is challenging. Since the manuscripts contain very few user's notes or instructions, any individual use is difficult to trace and might therefore remain invisible to modern-day scholars. I therefore cannot exclude a personal use of some of the songs or an individual use of a collection that was organized to facilitate a communal use.

Vernacular song obviously offered its users a variety of possibilities to develop a personalized devotion, and song manuscripts could easily be individualized through the addition of folios, quires, or texts, thus matching individual needs and supporting an inner spiritual development. Yet, although some manuscripts seem to have been produced for individual use or for personal ownership, the use of their contents was still largely situated in communal traditions of repertoire selection, book production, and group singing.

These dynamic descriptions of the use of song collections are not necessarily contradictory: it is possible to sing in chorus while individually concentrating on one's inner devotion. In this way, song collections are once more connected to the communal convent life. Convent life, in practice, consists of pursuing individual spiritual development within a common framework that is designed to encourage this personal growth. Within this 
framework, individual intention and common practice could take place simultaneously. Christians could, for instance, sing "I" all together and out loud but from a personal point of view, or they could integrate personal devotion and common tradition by meditating for themselves all together at the same place and time every week. In convent life, individual and community feature in constant interplay, expressed by vernacular song.

An integration of individual and community in song practice is also suggested by an illustration on fol. 33 verso of manuscript Leiden, UB, LTK 2058 (fig. 5). ${ }^{62}$ Although scholars agree that this collection was most probably compiled for purposes of personal devotion, the manuscript contains an image showing four sisters. Three of them hold books; two of those books are opened and being pored over by their users. An angel unfolds a

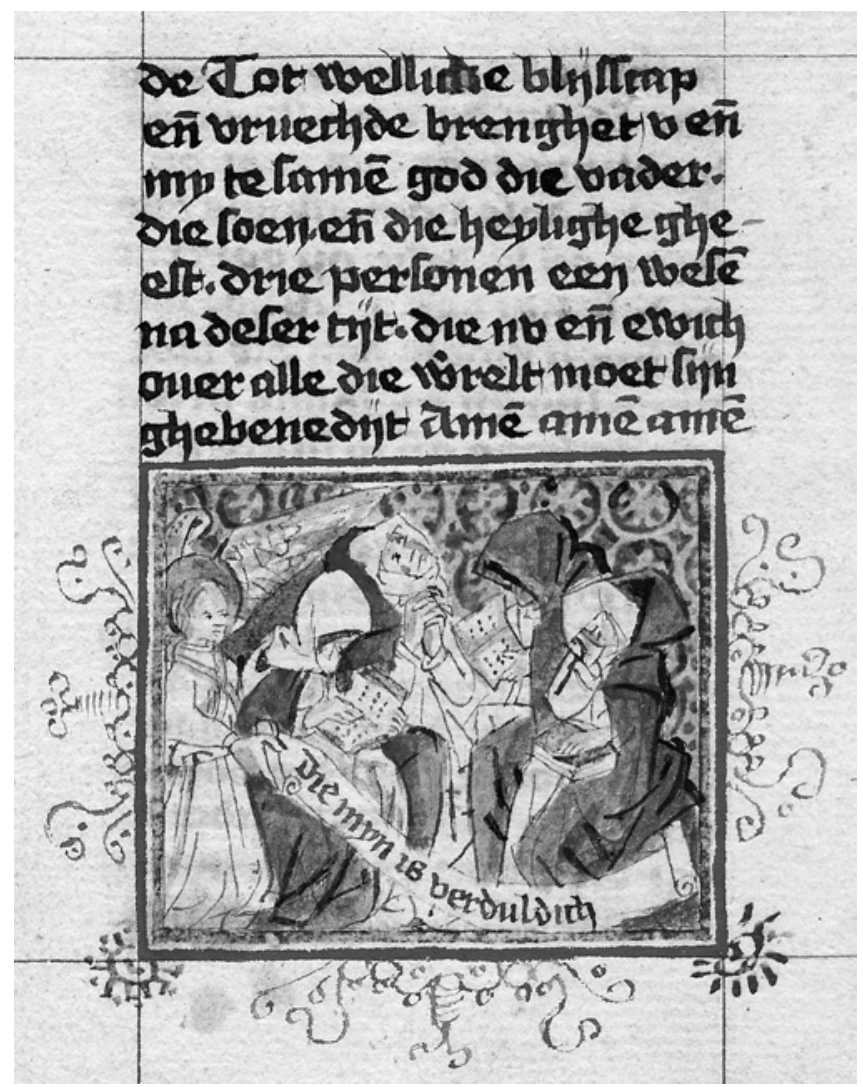

FIG. 5 "Sisters singing, reading or praying together alone," Leiden, Universiteitsbibliotheek, LTK 2058, fol. $33^{\mathrm{v}}$, ca. I470, (C) Universiteitsbibliotheek Leiden, reproduced with permission. 
banderole containing the words "Die myn is verduldich" [love is patient], a translation of I Cor. I3:4. According to the text on fol. 34 recto, next to the image, this love can be achieved by contemplating the songs presented. In view of the observations discussed in this article, I think it quite possible that the four sisters in this image are actually singing, reading, or praying the song together alone.

\section{LIST OF MANUSCRIPTS}

Berlin, Staatsbibliothek zu Berlin-Preußischer Kulturbesitz, manuscripta germanica in octavo 185 .

Berlin, Staatsbibliothek zu Berlin-Preußischer Kulturbesitz, manuscripta germanica in octavo I9o.

Berlin, Staatsbibliothek zu Berlin-Preußischer Kulturbesitz, manuscripta germanica in octavo 280 (the songbook of Anna of Cologne).

Brussels, Koninklijke Bibliotheek, II 263I.

Brussels, Koninklijke Bibliotheek, II 270-B.

Leiden, Universiteitsbibliotheek, BPL I289-II (the songbook of Jenneken Verelst).

Leiden, Universiteitsbibliotheek, LTK 2058 (the songbook of Etheken Berntsdachter).

Leiden, Universiteitsbibliotheek, LTK 2I8-III (the songbook of Marigen Remen).

Paris, Bibliothèque nationale de France, fonds Néerlandais 39 (the songbook of Liisbet Ghoeyuaers).

The songbook of Catharina Tirs; current whereabouts unknown.

The Werden songbook; current whereabouts unknown.

Vienna, Österreichische Nationalbibliothek, Codices, Series nova I2875.

\section{NOTES}

I would like to express my gratitude to Hermina Joldersma for her valuable comments on an earlier version of this article.

I. For example, R. Hofman, C. Caspers, P. Nissen, M. van Dijk, and J. Oosterman, eds., Inwardness, Individualization, and Religious Agency in the Late Medieval Low Countries. Studies in the Devotio Moderna and its Contexts (Turnhout, Belgium: Brepols, 20I9); N. Largier, "The Art of Prayer: Conversions of Interiority and Exteriority in Medieval Contemplative Practice," in Rethinking Emotion: Interiority and Exteriority in Premodern, Modern, and Contemporary Thought, ed. Rüdiger Campe and Julia Weber (Berlin: de Gruyter, 20I4), 58-7I; J. van Engen, "Multiple Options: The World of the Fifteenth-Century Church," Church History 77, no. 2 (2008): 257-84, at 270; J. Brantley, Reading in the Wilderness: Private Devotion and Public 
Performance in Late Medieval England (Chicago: University of Chicago Press, 2007). For examples specifically concerning lay believers, see S. Folkerts, "The Cloister or the City? The Appropriation of the New Testament by Lay Readers in an Urban Setting," in Cultures of Religious Reading in the Late Middle Ages: Instructing the Soul, Feeding the Spirit, and Awakening the Passion, ed. S. Corbellini (Turnhout, Belgium: Brepols, 20I3), I75-99; S. Folkerts, "Reading the Bible Lessons at Home: Holy Writ and Lay Readers in the Low Countries," Church History and Religious Culture 93, no. 2 (2013): 189-216.

2. For example, T. de Hemptinne, Veerle Fraeters, and María Eugenia Góngora, eds., Speaking to the Eye: Sight and Insight through Text and Image (1150-1650) (Turnhout, Belgium: Brepols, 2013); P. Saenger, Space between Words: The Origins of Silent Reading (Stanford, CA: Stanford University Press, I997); P. Saenger, "Books of Hours and the Reading Habits of the Later Middle Ages," in The Culture of Print: Power and the Uses of Print in Early Modern Europe, ed. R. Chartier (Cambridge: Polity Press, I989), I4I-73.

3. T. Mertens and D. van der Poel, "Individuality and Scripted Role in Devout Song and Prayer," in R. Hofman, C. Caspers, P. Nissen, M. van Dijk, and J. Oosterman, eds., Inwardness, Individualization, and Religious Agency in the Late Medieval Low Countries. Studies in the Devotio Moderna and its Contexts (Turnhout, Belgium: Brepols, 20I9); L. Vroomen, Ik heb mijn lief in eeuwigheid. Functies en thema's van Middelnederlandse devote liederen, collaties en viten (Hilversum, Netherlands: Verloren, 20I7); U. Hascher-Burger, "Religious Song and Devotional Culture in Northern Germany," in A Companion to Mysticism and Devotion in Northern Germany in the Late Middle Ages, ed. E. Andersen, H. Lähnemann, and A. Simon (Leiden, Netherlands: Brill, 2OI4), 26I-83; D. van der Poel, "Late-Medieval Devout Song: Repertoire, Manuscripts, Function," in Dialog mit den Nachbarn. Mittelniederländische Literatur zwischen dem 12. und 15. Jahrhundert = Zeitschrift für Deutsche Philologie Sonderheft zum Band I30 (20II), 67-79, at 73-79; T. Mertens, "Die gheestelicke melody: A Program for the Spiritual Life in a Middle Dutch Song Cycle," in Women and Experience in Later Medieval Writing: Reading the Book of Life, ed. A. Mulder-Bakker and L. Herbert McAvoy (New York: Palgrave Macmillan, 2009), I23-47; U. Hascher-Burger and H. Joldersma, "Introduction: Music and the Devotio Moderna," Church History and Religious Culture 88, no. 3 (2008): 313-32; U. Hascher-Burger, "Music and Meditation: Songs in Johannes Mauburnus's Rosetum exercitiorum spiritualium," Church History and Religious Culture 88, no. 3 (2008): 347-69; F. Van Buuren, “'Soe wie dit lietdkyn sinct of leest': De functie van de Laatmiddelnederlandse geestelijke lyriek," in Een zoet akkoord. Middeleeuwse lyriek in de Lage Landen, ed. Frank Willaert et al. (Amsterdam: Prometheus, I992), 234-54, 399-404.

4. C. Burger, "Late Medieval Piety Expressed in Song Manuscripts of the Devotio Moderna," Church History and Religious Culture 88, no. 3 (2008): 329-45, at 329-30; Hascher-Burger, "Religious Song and Devotional Culture in Northern Germany," 265, 274; Van Buuren, "Soe wie dit lietdkyn sinct of leest"; and the introductions to Het liedboek van Liisbet Ghoeyuaers, ed. A. J. M. van Seggelen (Zwolle, Netherlands: Tjeenk Willink, I966) and Het liedboekje van Marigen Remen (hs. Leiden, U.B., ltk. 2I8, F.62-F.78V), ed. W. P. Gerritsen et al. (Utrecht, Netherlands: Ruygh-Bewerp I, I966).

5. B. Hamm, "Frömmigkeit als Gegenstand theologieverschichtslicher Forschung," Zeitschrift für Theologie und Kirche 74, no. 4 (I977): 464-97, at 466-7I, cf. Largier, "The Art of Prayer."

6. Not addressed here are questions of mentality, originality, or the intended effects of specific practices on the inner self. I will also not discuss whether devotional singing practices were voiced or silent. These issues have been adequately addressed by other scholars; see notes 3 and 4 .

7. H. Joldersma, "Alternative Spiritual Exercises for Weaker Minds? Vernacular Religious Song in the Lives of Women of the Devotio Moderna," Church History and Religious Culture 88, no. 3 (2008): $37 \mathrm{I}-93$, at $372-93$.

8. I define convent in the broadest sense, including all kinds of religious communities of inhabitants leading a communal religious life that was guided by rules resembling the monastic rules of obedience, poverty, and chastity. For an overview of the different convents and communities in the Low Countries, see T. Mertens, "Praying in the Vernacular. Middle Dutch Imitative Forms of the Divine Office from the I370s to I520s," in Nuns' Literacies in Medieval Europe: The Hull Dialogue, ed. V. Blanton, V. O'Mara, and P. Stoop (Turnhout, Belgium: Brepols, 2013), 133-46.

9. I understand liturgy as the ritualized worship of God, comprising a complex of texts, chants, gestures, and other usages: Oxford Music Online, Grove Music Online, the Oxford Dictionary of Music, the Oxford Companion to Music (Oxford University Press), http://www.

This content downloaded from

131.211.104.202 on Wed, 11 Dec 2019 12:14:17 UTC

All use subject to https://about.jstor.org/terms 
oxfordmusiconline.com/, lemma "liturgy." J. Harper, The Forms and Orders of Western Liturgy from the Tenth to the Eighteenth Century: A Historical Introduction and Guide for Students and Musicians (Oxford: Clarendon Press, I991), I2; H. Auf der Maur, Gottesdienst der Kirche: Handbuch der Liturgiewissenschaft. Band V: Feiern im Rhythmus der Zeit 1 (Regensburg, Germany: Pustet, I983), at 24-25. Some scholars confined the term to forms of public worship that were approved by the higher church officials, most notably the services of Mass and Divine Office. This confined definition was, for instance, applied by Janota, who insisted that medieval vernacular religious song must be embedded in such official services to be attributed a liturgical function. J. Janota, Studien zu Funktion und Typus des Deutschen geistlichen Liedes im Mittelalter (Munich: Beck, I968), I49. Yet, this definition is problematic to song research, since the sources rarely allow deciding whether songs were sufficiently embedded to be considered liturgical repertoire. Janota's viewpoint eventually resulted in the creation of the term para-liturgy for nonembedded forms of ritualized worship, e.g., I. de Loos, "Van kaarsen en kerken. Liturgie, paraliturgie of géén liturgie?” in Patronen ontrafeld: studies over gregoriaanse gezangen en Middelnederlandse liederen, ed. José van Aelst, Dieuwke van der Poel, Els Rose and Karl Kügle (Hilversum, Netherlands: Verloren, 20I2), I83-97, at 22I. However, this concept is rendered superfluous by the extension of the definition of liturgy to include all forms of ritualized worship. Moreover, this broader definition of liturgy does more justice to the musical variety of late medieval worship. S. Boynton, "Religious Soundscapes: Liturgy and Music," in The Cambridge History of Christianity, Part IV, Christianity in Western Europe, c.1100-c.1500, ed. M. Rubin and W. Simons (Cambridge: Cambridge University Press, 2009), 238-53.

Io. All twelve manuscripts are listed at the end of this article. The Tirs songbook was probably finished in 1588 , but it is nevertheless included here because its repertoire selection bears more resemblance to earlier songbooks than to songbooks dating from the second half of the sixteenth century.

II. This is opposed to smaller collections of two to sixteen songs, which are usually included among other texts in prayer books, meditation books, and other types of multitext codices.

I2. The manuscripts containing Latin repertoire are: Berlin, Staatsbibliothek zu BerlinPreußischer Kulturbesitz, manuscripta germanica in octavo I९०; Berlin, Staatsbibliothek zu Berlin-Preußischer Kulturbesitz, manuscripta germanica in octavo 280; Brussels, Koninklijke Bibliotheek, II 2631; Brussels, Koninklijke Bibliotheek, II 270-B; Paris, Bibliothèque nationale de France, fonds Néerlandais 39; Vienna, Österreichische Nationalbibliothek, Codices, Series nova I2875; and the songbook of Catharina Tirs.

I3. Three collections also contain songs with nonreligious or secular lyrics; this is not as simple a distinction as one might first think, but this is beyond the scope of this article; see $\mathrm{H}$. Joldersma, “'Geestelijke' en 'wereldlijke' liederen: Enige aspecten van het handschrift Brussel MS II, 263I," in Veelderhande liedekens: Studies over het Nederlandse lied tot 1600, ed. F. Willaert (Leuven, Belgium: Peeters, I997), 58-73. Brussels, KB, II 263I, contains six secular songs (no. 3 I through 36 of the collection) and sixty-two devout songs; Leiden, Universiteitsbibliotheek, LTK 2I8-III, contains two secular songs (no. 5 and 9) and fifteen devout songs; Leiden, Universiteitsbibliotheek, BPL I289-II, contains ten secular songs (no. 3, 8, I2-I4, I6, 20, 2I, 24,26 ) and sixteen devout songs. All song numbers mentioned in this article are additions by modern scholars; the manuscripts do not provide numerations.

I4. The manuscripts containing musical notation are: Berlin, SBB-PK, mgo I9o; Berlin, SBB-PK, mgo 280; Brussels, KB, II 270-B; Brussels, KB, II 263I; Vienna, ÖNB, cod. ser. n. I2875; and the Tirs songbook. Musical notation is provided for most Latin songs, as well as for some vernacular songs.

I5. This reservation is based on manuscripts from male monasteries containing Middle Dutch religious songs among other texts. A few examples: Gaesdonck, Bibliothek des Collegium Augustinianum ms 37 (canons regular in Gaesdonck); Brussels, Koninklijke Bibliotheek IV 42I (canons regular in Tongeren); Utrecht, Universiteitsbibliotheek I6H34 (at least one quire of this manuscript originates from the brethren of the common life in Deventer).

I6. H. van Engen and G. Verhoeven, eds., Monastiek observantisme en Moderne Devotie in de Noordelijke Nederlanden (Hilversum, Netherlands: Verloren, 2008); Van Engen, "Multiple Options."

I7. C. de Morrée, Voor de tijd van het jaar. Vervaardiging, organisatie en gebruikscontext van Middelnederlandse devote liedverzamelingen (ca.1470-1588) (Hilversum, Netherlands: Verloren, 20I7), 202-56; J. van Dongen, "Een devoot ende profitelijck boecxken. Terug naar de bron" (PhD diss., Radboud Universiteit Nijmegen, 20II). 
I8. De Morrée, Voor de tijd van het jaar, 283-85, 293-95, 302. The collections in Vienna, ÖNB, cod. ser. n. I2875, and in Berlin, SBB-PK, mgo I9O, have four groups of a total of fifteen songs in common. The collections in Vienna, ÖNB, cod. ser. n. I2875, and in Leiden, Universiteitsbibliotheek, LTK 2058 , have a group of nineteen songs in common. The first nine of these, again in the same order, are also transmitted in the prayer book The Hague, Koninklijke Bibliotheek, $75 \mathrm{H}_{42}$.

I9. Berlin, SBB-PK, mgo 280, fol. Ir. A similar comment was written in the songbook of prioress Jenneken Verelst, Leiden, UB, BPL I289, fol. 2r.

20. Tirs songbook, as in Niederdeutsche geistliche Lieder und Sprüche aus dem Münsterlande, ed. B. Hölscher (Berlin: W. Hertz, ı854).

2I. Het liedboek van Liisbet Ghoeyuaers, ed. Van Seggelen, I3-24; W. Kohl, Das Bistum Münster, vol. I, Die Schwesternhäuser nach der Augustinerregel (Berlin: De Gruyter, I968), I99, 201; J. Oosterman, “Jenneken Verelst en Anna Bijns. Nieuws over handschrift Leiden, UB, BPL I289 en zijn inhoud," Spiegel der Letteren 42, no. I (2000): 49-57, at 52. The mark of the convent that was written in the manuscript Berlin, Staatsbibliothek zu Berlin-Preußischer Kulturbesitz, manuscripta germanica in octavo I85, possibly contained the name of an individual as well, but this was partially erased; cf. C. de Morrée, "Komt het Deventer liederenhandschrift wel uit Deventer?” Spiegel der Letteren 55, no. 2 (2013): I2I-32, at I26.

22. K. Stooker and T. J. Verbeij, eds., Collecties op orde: Middelnederlandse handschriften uit kloosters en semi-religieuze gemeenschappen in de Nederlanden (Leuven, Belgium: Peters, I997), I:136-45.

23. Paris, BnF, Néerl. 39, fol. 22v.

24. Paris, BnF, Néerl. 39, fol. 8ov.

25. Johanna Cueliens was prioress in the convent of Rich Clares in Brussels in the second half of the sixteenth century. The manuscript was probably produced in this same convent ca. I475-I525 and probably remained there until the early seventeenth century; cf. Van Seggelen, Het liedboek van Liisbet Ghoeyuaers, I3-24.

26. Leiden, UB, LTK 2058 , fol. Ir. At some point someone attempted to erase the part "ende na mijnre doet so gheve icket int ghemeen" [and after my death I give it to become common property]. This has led some scholars to presume that the book might never have been donated to the community after all; cf. Die Gheestelicke Melody. Ms. Leiden, University Library, Ltk. 2058, ed. P. F. J. Obbema (Leiden, Netherlands: New Rhine Publishers, I975), esp. p. X.

27. Only four collections do not contain any later additions: the smaller collections in Leiden, UB, LTK 2058 (nineteen songs with prose introductions), Leiden, UB, LTK 2I8-III (I7 songs), and the Werden songbook (twenty-three songs), as well as the collection in Brussels, KB, II 270-B (forty-two songs, five prayers, seven other short texts).

28. This kind of manuscript can be characterized as "open-ended." For a detailed description of these dynamic growing and compilation processes, see C. de Morrée and D. van der Poel, "Authorial and Editorial Roles in Song Manuscripts of the Devotio Moderna," in The Dynamics of the Medieval Manuscript-Text Collections from a European Perspective, ed. Karen Pratt, Bart Besamusca, Matthias Meyer, and Ad Putter (Göttingen, Germany: V\&R unipress, 20I7), 367-88, at 375-84; de Morrée, Voor de tijd van het jaar, esp. I87-88.

29. That this extension was indeed made by the second scribe follows from the prickings in the manuscript. The scribes used a slightly different method for pricking the folia, resulting in round-shaped prickings in the quires copied by the first scribe and flat-shaped prickings in the quires copied by the second scribe. The pages that were prepared by the first scribe and written on by the second are pricked twice, in both manners.

30. Van Seggelen, Het liedboek van Liisbet Ghoeyuaers, I-24; a complete codicological description of this manuscript and its genesis is included in de Morrée, Voor de tijd van het jaar, I44-46, 340-47.

3I. The scribes B, C, D, E, G, and H work in a way that is similar to the manner of scribe A, with the exception of the paragraph signs that are only used by scribe C. Scribes F and I write in a different kind of script, vary in the number of rules on a page, and $\mathrm{F}$ uses a different kind of heading than the other scribes (it is no melody reference but a general characterization of the song it refers to). A complete codicological description of this manuscript and its genesis is included in de Morrée, Voor de tijd van het jaar, 65-67, 316-25.

32. The initial collection starts with a large group of Christmas songs. One of the quires copied by the second scribe also contains a collection of Christmas songs, yet no effort was made to place both Christmas groups next to one another. In Middle Dutch religious song collections, Christmas songs are always grouped together. It is therefore unlikely that the 
initial collection was designed as an elaboration on the fragmented quires; it is far more likely that these quires are later insertions. A complete codicological description of this manuscript and its genesis is included in de Morrée, Voor de tijd van het jaar, I24-26, 326-39.

33. The third manuscript is Brussels, KB, II 263I. Compare with Het liederenhandschrift Berlijn 190. Hs. Staatsbibliothek zu Berlin-Preußischer kulturbesitz, germ. oct. 190, ed. T. Mertens, D. E. van der Poel, G. Gerritsen-Geywitz, K. Goudriaan, H. Joldersma, I. de Loos, and J. Oosterman (Hilversum, Netherlands: Verloren, 2013), I4-I5; Tien Middelnederlandse meerstemmige liederen uit handschrift Brussel KB II.270, ed. J. van Dongen (Utrecht, Netherlands: Koninklijke Vereniging voor Nederlandse Muziekgeschiedenis, 2002), 37-40; I. De Loos and D. van der Poel, "Het liederenhandschrift Brussel KB II 263I. Samenstelling en repertoire," Queeste 8, no. 2 (200I): 97-II9, at I25. For a definition of liturgy, see note 9.

34. Mertens and van der Poel, "Individuality and Scripted Role in Devout Song and Prayer"; Mertens, "Die gheestelicke melody"; Hascher-Burger, "Music and Meditation"; Hascher-Burger, "Religious Song and Devotional Culture in Northern Germany."

35. Vroomen, Ik heb mijn lief in eeuwigheid.

36. De Morrée, Voor de tijd van het jaar, 3I-40, 99-I00, 247-55, 29I-97; Joldersma, "Alternative Spiritual Exercises for Weaker Minds?" 372-93, and the remarks in note 9. Outside my corpus, a few manuscripts are known that contain — among many other texts - a few Middle Dutch religious songs that were probably used in liturgical celebrations in secular churches. I. de Loos, "De interactie tussen liturgische zang en niet-liturgische liederen," Ons Geestelijk Erf 76, no. I-3 (2002): I55-76, at 55-I57, I75.

37. De Morrée, Voor de tijd van het jaar, 43-53, 99-100, I83-20I, I89-20I; de Morrée and van der Poel, "Authorial and Editorial Roles," 375-84; van der Poel, "Late-Medieval Devout Song," $75-77$.

38. De Morrée, Voor de tijd van het jaar, I83-20I, 253-56, 28I-83. Of course, there are exceptions, such as the Passion song "Innichlike wyl wy heven an, myt love wylle wy syngen" [We shall passionately begin, we shall sing with praise] (Tirs songbook, no. I9) and the Christmas song "O here, der hemelen stichter" [Oh, Lord, founder of heaven] (Berlin, SBB-PK, mgo I85, no. 57).

39. Berlin, SBB-PK, mgo 280, song 37. See also Liederbüch der Anna von Köln (um 1500), ed. W. Salmen and J. Koepp (Düsseldorf, Germany: Schwann, I954).

40. Berlin, SBB-PK, mgo I90, song I07.

4I. Berlin, SBB-PK, mgo I85, song I3.

42. Tirs songbook, song I8.

43. Berlin, SBB-PK, mgo I9o, song 58.

44. Paris, BnF, Néerl. 39, song 3I.

45. Berlin, SBB-PK, mgo I90, song 52.

46. Tirs songbook, song 3.

47. Berlin, SBB-PK, mgo I90, song 53.

48. Paris, BnF, Néerl. 39, song 20.

49. Paris, BnF, Néerl. 39, song 20.

50. Berlin, SBB-PK, mgo I85, song 25.

51. Berlin, SBB-PK, mgo I85, song 30.

52. P. Zumthor, Essai de poétique médiévale (I972; repr., Paris: Seuil, 2000), 2II-I4.

53. Joldersma, “Alternative Spiritual Exercises for Weaker Minds?” 372-93.

54. Joldersma, “Alternative Spiritual Exercises for Weaker Minds?" 388-89; de Loos, "De interactie tussen liturgische zang en niet-liturgische liederen," at 55-I57, I75; de Loos, "Van kaarsen en kerken," 22I, 225; U. Hascher-Burger, Gesungene Innigkeit: Studien zu einer Musikhandschrift der Devotio Moderna (Utrecht, Universiteitsbibliotheek, ms. 16 H 34, olim B 113): Mit einer Edition der Gesänge (Leiden: Brill, 2002), I85-240; W. Lipphardt, "Die liturgische Funktion Deutscher Kirchenlieder in den Klöstern Niedersächsischer Zisterzienserinnen des Mittelalters," Zeitschrift für Katholische Theologie 94, no. 2 (1973): I58-98, at I58-60, I77-79, I9I; Janota, Studien zu Funktion und Typus des Deutschen geistlichen Liedes im Mittelalter, I25-50.

55. De Morrée, Voor de tijd van het jaar, I90, 283-84, 303; van der Poel, "Late-Medieval Devout Song," 75-77.

56. Van Seggelen, Het liedboek van Liisbet Ghoeyuaers, I-24; de Morrée, "Deventer liederenhandschrift,” I28-30; de Morrée, Voor de tijd van het jaar, 207-8, 228.

57. Mertens and van der Poel, "Individuality and Scripted Role in Devout Song and Prayer"; Mertens, "Die gheestelicke melody."

58. Fol. 3IV and fol. 32r. See also note 26. 
59. See note I8.

60. "Dit heft hy verkündiget den bisschop, die groot afflaet heft gegeven den genen die dit lijtgen bij sich draegen, lesen of syngen, hoeren lesen of syngen. Oeck sullen sy seker sijn voer der quader suecten der pocken" [This he told the bishop, who granted a plenary indulgence to those who carry this song with them, read it, sing it, hear it being read to them or hear it being sung. They will also be secure from the malicious illness of smallpox.] "Eine Werdener Liederhandschrift aus der Zeit um I500," ed. F. Jostes, Jahrbuch des Vereins für Niederdeutsche Sprachforschung I4 (I888): 60-89, at 66.

6I. Saenger, "Books of Hours," I56.

62. Obbema, Die Gheestelicke Melody, fol. 33v. This is a black-and-white facsimile edition of the manuscript. 